\title{
Kuluttajille tietoa tuotteiden ympäristövaikutuksista valintojen tueksi
}

Mira Povelainen

Raisio Oyj, Raisionkaari 55, 21201 Raisio

mira.povelainen@raisio.com

\section{Tiivistelmä}

Väestönkasvu, ilmastonmuutos ja elintason nousu tulevat näkymään ruoan kysynnän kasvuna ja kulutustottumusten muutoksena. Ruoantuotannon kasvattaminen on haaste ekosysteemille jo sinällään. Samaan aikaan ilmastonmuutos vaikeuttaa tilannetta entisestään. Vettä on tulevaisuudessa yhä useammin joko liikaa tai liian vähän.

Suomalaisten kulutuksen ympäristövaikutuksista ruoan osuuden arvioidaan olevan noin kolmannes ja hiilijalanjäljestäkin osuus on 20-25\%. Ekologiset ruokavalinnat ovat tutkimusten mukaan monelle suomalaiselle kuluttajalle edelleen kysymysmerkki. Kuluttajien ympäristötietoisuudesta ja valinnoista on saatu viime aikoina tuoretta tutkimustietoa. Climate Focus Nordic -tutkimus sisältää ensimmäistä kertaa vertailukelpoista ja kattavaa tietoa kuluttajien käyttäytymisestä ja asenteista eri Pohjoismaissa. Tutkimuksen mukaan jo $35 \%$ suomalaisista on valmiita toimimaan ympäristön hyväksi omien ruokavalintojensa kautta.

Jotta kuluttajalla olisi tulevaisuudessa tietoa omien valintojensa merkityksestä ympäristöllemme, Raisio on alkanut merkitä tuotteitaan hiilijalanjälkimerkillä, joka kertoo tuotteen valmistuksen aiheuttamat kasvihuonekaasupäästöt pellolta kaupan varastoon. Ensimmäisenä tuotteena hiilijalanjäljestä kertovan merkinnän sai Elovena-kaurahiutale vuonna 2008 ja vuoden 2009 aikana merkintää laajennettiin kahteen uuteen tuotteeseen. Kuluttajien antama palaute tuotteiden hiilijalanjälkimerkeistä oli erittäin positiivista. Koska tämäntyyppiselle tiedolle oli selkeä tarve, vuoden 2009 aikana Raisio alkoi myös itse laskea tuotteilleen hiilijalanjälkiä.

Ilmastonmuutoksen on ennustettu aiheuttavan kiihtyvää globaalia pulaa vedestä. Vain yksi prosentti maailman vesivaroista on juomavedeksi ja viljelyyn sopivaa makeaa vettä. Tästä noin $70 \%$ käytetään maatalouden tarpeisiin. Vesijalanjälki kertoo tuotteen kokonaisvedenkulutuksen koko tuotantoketjussa pellolta valmiiksi pakatuksi tuotteeksi asti, sisältäen kasvin kasvuunsa käyttämän veden, tuotteen valmistukseen käytetyn veden sekä jäteveden. Raision Elovena-kaurahiutaleen vesijalanjäljeksi on laskettu $101 \mathrm{l} / 100 \mathrm{~g}$ tuotetta.

Asiasanat: elintarvikkeet, hiilijalanjälki, vesijalanjälki, pakkausmerkinnät 


\title{
Kuluttajille tietoa tuotteiden ympäristövaikutuksista valintojen tueksi
}

\author{
Mira Povelainen \\ Raisio Oyj, Raisionkaari 55, 21201 Raisio \\ mira.povelainen@raisio.com
}

\section{Johdanto}

Väestönkasvu ja elintason nousu erityisesti Aasiassa lisäävät ruoan kysyntää. Ilmastonmuutos, bioenergian kasvava tuotanto, kaupungistuminen ja saastuminen uhkaavat pienentää ruoan tuotantoalaa ja siten globaali kysynnän ja tarjonnan välinen ristiriita muodostuu yhä haastavammaksi niin ekologisesti kuin eettisestikin. Globaalisti ruoan kysynnän kasvu väkiluvun kasvaessa on viljan tuotannossa kyetty tähän asti tyydyttämään keinokastelulla ja lannoituksella, joiden myötä satotasot ovat kasvaneet. Peltopinta-ala ei kuitenkaan ole kasvanut enää vuosikymmeniin. Vuonna 2050 maailman väkiluku on arviolta noin 9,2 miljardia ja ruoan kysynnän on arvioitu jopa kolminkertaistuvan. Vastaavasti viljelyala henkilöä kohden pienenee olennaisesti. Nykyisillä kulutustottumuksilla maapallolla ei pystytä tuottamaan kysyntää vastaavaa määrää ruokaa. Ruoan riittävyyden turvaaminen onkin yksi tulevaisuuden merkittävimmistä haasteista. Kasvipohjainen ja kansallisella tasolla tuotettu ruoka on vastaus moneen globaaliin kysymykseen puhuttaessa ruuan riittävyydestä sekä sen tuotannon eettisyydestä ja ekologiasta, mutta myös ruokatuotannon energiatehokkuuteen tullaan kiinnittämään nykyistä enemmän huomiota. Elintarvikeketjun murroksella on kaikkiin ketjussa toimiviin lyhyen ja pitkän aikavälin vaikutuksia. Suomen kilpailuasema maana vahvistunee ruokaketjun murroksessa. Erityisesti veden muodostuessa eläinpohjaisessa ruokaketjussa niukkuustekijäksi, tulee Suomen kaltaisen maan, jossa on runsaat vesivarat ja paljon vapaata pinta-alaa, asema vahvemmaksi. Jatkossa Suomen sopivuus liha- ja maitotuotantoalueena suhteellisesti vahvistuu.

\section{Kuluttajien ympäristötietoisuus}

Suomalaisten kulutuksen ympäristövaikutuksista ruoan osuuden arvioidaan olevan noin kolmannes ja hiilijalanjäljestäkin osuus on 20-25\%. Ei siis ole yhdentekevää, mitä syömme. Silti ekologiset ruokavalinnat ovat tutkimusten mukaan monelle suomalaiselle kuluttajalle edelleen kysymysmerkki. Kuluttajien ympäristötietoisuudesta ja valinnoista on saatu viime aikoina tuoretta tutkimustietoa. Climate Focus Nordic -tutkimus (syyskuu 2009) sisältää ensimmäistä kertaa vertailukelpoista ja kattavaa tietoa kuluttajien käyttäytymisestä ja asenteista eri Pohjoismaissa. Tutkimuksessa pystyttiin jaottelemaan kuluttajat kuuteen eri luokkaan sen mukaan miten ympäristöön liittyvät asiat vaikuttavat heidän ostopäätöksissään. Tutkimuksen tulosten mukaan jo 35 \% suomalaisista on valmiita toimimaan ympäristön hyväksi omien ruokavalintojensa kautta. On siis olemassa huomattava joukko kuluttajia, jotka ovat valmiita ja halukkaita toimimaan myös ilmastonmuutoksen hidastamiseksi. Flash Eurobarometrin (huhtikuu 2009) tekemän kyselytutkimuksen mukaan jopa $70 \%$ eurooppalaisista haluaisi hiilijalanjäljen pakolliseksi tuotteisiin.

\section{Hiilijalanjälki}

Jotta kuluttajalla olisi tulevaisuudessa tietoa omien valintojensa merkityksestä ympäristöllemme, Raisio on alkanut merkitä tuotteitaan hiilijalanjälkimerkillä, joka kertoo tuotteen valmistuksen aiheuttamat kasvihuonekaasupäästöt pellolta kaupan varastoon. $\mathrm{CO}_{2} \mathrm{e}$-mittarin laskentamalli pohjautuu Maa- ja elintarviketalouden tutkimuskeskuksen tutkimuksiin. Luvun laskentamenetelmä perustuu ISO 14040- ja ISO 14044-standardeihin sekä kansainvälisen ilmastopaneelin (IPCC) periaatteisiin. Ensimmäisenä tuotteena hiilijalanjäljestä kertovan merkinnän sai Elovena-kaurahiutale vuonna 2008 ja vuoden 2009 aikana merkintää laajennettiin kahteen uuteen tuotteeseen. Kuluttajien antama palaute tuotteiden hiilijalanjälkimerkeistä oli erittäin positiivista. Koska tämäntyyppiselle tiedolle oli selkeä tarve, vuoden 2009 aikana Raisio alkoi myös itse laskea tuotteilleen hiilijalanjälkiä. Laskenta aloitettiin yhteistyössä Lappeenrannan teknillisen yliopiston kanssa diplomityön muodossa. 
Tarkasteltavat tuotteet olivat Raision uudet Torino-tuoteryhmään kuuluvat ohratuotteet, joita voi käyttää aterialisäkkeinä esim. riisin tapaan. Laskennan tuloksena saatiin Torino täysjyväohran hiilijalanjäljeksi $110 \mathrm{gCO}_{2} \mathrm{e} / 100 \mathrm{~g}$ ja Torino ohrahelmen $195 \mathrm{gCO}_{2} \mathrm{e} / 100 \mathrm{~g}$. Suurin osa ohratuotteiden hiilijalanjäljestä muodostuu alkutuotannossa eli ohran viljelyssä. Prosessoinnin, pakkauksen ja kuljetusten osuus oli vähäinen. Tulosten herkkyystarkastelussa havaittiin, että ohratuotteiden hiilijalanjälkilaskenta on herkkä tietyille vaiheille tuotantoketjussa. Herkimmiksi muuttujiksi osoittautuivat viljelyssä typen vapautuminen maaperästä, satotaso sekä tuotteen prosessoinnin saanto. Erityisesti prosessoinnin epäsuora vaikutus alkutuotannosta syntyviin kasvihuonekaasupäästöihin oli merkitsevä. Näin ollen tutkimuksessa oli myös löydettävissä yhteys hiilijalanjälkilaskennalle ja yritysten ympäristövastuullisuudelle.

\section{Vesijalanjälki}

Suomessa vettä riittää, mutta maailmanlaajuisesti tilanne ei ole yhtä hyvä. Ilmastonmuutoksen on ennustettu aiheuttavan kiihtyvää globaalia pulaa vedestä. Vain yksi prosentti maailman vesivaroista on juomavedeksi ja viljelyyn sopivaa makeaa vettä. Tästä noin 70 \% käytetään maatalouden tarpeisiin. Raisio laski Elovena-kaurahiutaleelle vesijalanjäljen. Vesijalanjälki kertoo tuotteen

kokonaisvedenkulutuksen koko tuotantoketjussa pellolta valmiiksi pakatuksi tuotteeksi asti, sisältäen kasvin kasvuunsa käyttämän veden, tuotteen valmistukseen käytetyn veden sekä jäteveden. Suurin osa vedenkulutuksesta on kauran kasvuaikanaan käyttämää vettä, minkä se saa normaalin kiertokulun kautta sadevetenä. Suomessa viljeltyä kauraa ei keinokastella eli se ei kilpaile puhtaan juomaveden kanssa. Raisio loi itse laskentamallin sillä vakiintunutta kansainvälistä laskentamallia ja tuotteisiin merkitsemisen tapaa ei vielä ole. Alkutuotannon osalta laskennassa käytettiin Ilmatieteenlaitoksen säähavaintopisteiden haihduntamittaustietoja, kauran viljelyn vedenkulutusta ja sopimusviljelijöiden toimittaman kauran keskisatoja kolmelta vuodelta. Kaurahiutaleiden valmistuksen ja pakkausmateriaalien yhteenlaskettu osuus kokonaisvedenkulutuksesta on reilusti alle yksi prosentti. Valmistusprosessista ei synny jätevettä, sillä kaurahiutaleet höyrytetään. Elovena-kaurahiutaleiden vesijalanjälki on 101 litraa/ 100g tuotetta.

\section{Johtopäätökset}

Kuluttajat toivovat tuotteiden ympäristövaikutuksista kertovia tietoja pakkauksiin ja haluavat niiden avulla vertailla tuotteita. Ongelmalliseksi tilanteen tekee se, että vaikka hiilijalanjälkiä on jo joitakin vuosia laskettu erilaisille tuotteille, tulosten vertailtavuus on erittäin vaikeaa, koska kattava kansainvälinen standardi tuotteiden hiilijalanjäljen laskemiselle puuttuu. Vesijalanjäljen osalta ollaan vielä huomattavasti kauempana standardointikelpoisesta laskentatavasta. Oma rajoituksensa tulee vastaan myös siinä, kuinka monta erilaista merkintää kuluttajapakkaukseen on mahdollista laittaa, niin että ne säilyttävät informatiivisen luonteensa. Koska kuluttajien keskuudessa on kuitenkin selvästi havaittavissa tarve pakkausmerkinnälle, joka kertoo tuotteen ympäristövaikutuksista, tarvitaan tulevaisuudessa kehitystä suuntaan, jossa yhdellä merkinnällä voidaan kuvata tuotteen kokonaisympäristövaikutuksia. 